Pustaka Karya: Jurnal Ilmiah Ilmu Perpustakaan dan Informasi Vol. 9 No. 1, Juni 2021, Hal 23-36

https://dx.doi.org/10.18592/pk.v9i1.5163

ISSN (p) : 2089-5216 | ISSN (e) : 2723-7699

\title{
Program pengembangan minat baca di Perpustakaan Kota Banjar Patroman ${ }^{1}$ Anwar Abdul Majid
}

${ }^{1}$ Program Studi Ilmu Perpustakaan dan Sains Informasi Fakultas Ilmu Komunikasi Universitas Padjajaran ${ }^{1}$ Hegarmanah, Jl. Raya Bandung - Sumedang KM. 21 Jatinangor, Sumedang Regency, West Java 45363 Email : ${ }^{1}$ anwar.abdulmajiid@gmail.com

\begin{abstract}
The City Library of Banjar Patroman has one program in developing interest in reading, especially for early childhood in PAUD, TK and RA in Banjar Patroman City. This study focuses on the management of the Reading and Literacy Tourism program in the aspect of POAC (Planning, Organizing, Actuating, Controlling). The research method used is descriptive qualitative method. Research data obtained through interviews, observation and document analysis. The analysis uses several objects in the form of behavior, perception, motivation, action, and others holistically. The Banjar Patroman City Library uses the planning concept that has been regulated in the Terms of Reference (KAK), then there are 15 organizing committees divided into 6 divisions, the implementation is carried out 2 times a week or 24 times a year and the implementation of this activity is carried out when Covid-19 pandemic with a limitation of 20 participants consisting of accompanying teachers and participants, supervision of this activity uses direct supervision, indirect supervision, internal supervision and external supervision. The results of this study indicate that the Banjar Patroman City Library in developing early childhood reading interest through Reading and Literacy Tourism activities in managing its activities uses the POAC aspect.
\end{abstract}

Keywords: banjar patroman city library; development of reading interest, reading and literacy tourism, $P O A C$

\begin{abstract}
ABSTRAK
Perpustakaan Kota Banjar Patroman memiliki salah satu program dalam mengembangkat minat baca, khususnya untuk anak usia dini di PAUD, TK dan RA yang terdapat di Kota Banjar Patroman. Penelitian ini berfokus pada pengelolaan program Wisata baca dan literasi dalam aspek POAC (Planning, Organizing, Actuating, Coontrolling). Metode penelitian yang digunakan adalah metode kualitatif deskriptif. Data penelitian diperoleh melalui wawancara, observasi dan analisis dokumen. Analisis menggunakan beberapa objek berupa perilaku, persepsi, motivasi, tindakan, dan lain lain secara holistik, dan dengan cara deskripsi. Perpustakaan Kota Banjar Patroman menggunakan konsep perencanaan yang sudah diatur dalam Kerangka Acuan Kerja (KAK), lalu pengorganisasian terdapat 15 orang panitia yang terbagi dalam 6 divisi, pelaksanaan dilakukan sebanyak 2 kali dalam satu minggu atau 24 kali dalam satu tahun dan penyelenggaraan kegiatan ini dilaksanakan ketika pandemi Covid-19 dengan pembatasan peserta 20 orang yang terdiri dari guru pendamping dan peserta, pengawasan pada kegiatan ini menggunakan pengawasan langsung, pengawasam tidak langsung, pengawasaninternal dan pengawasan external. Hasil penelitian ini menunjukkan bahwa Perpustakaan Kota Banjar Patroman dalam mengembangkan minat baca anak usia dini melalui kegiatan Wisata baca dan literasi dalam pengelolaan kegiatannya menggunakan aspek POAC.
\end{abstract}

Kata Kunci: pengembangan minat baca; poac; perpustakaan kota banjar patroman; wisata baca dan literasi 


\section{PENDAHULUAN}

Dalam Undang-undang No. 43 Tahun 2007 bab 1 pasal 1 tentang Perpustakaan disebutkan bahwa perpustakaan berfungsi sebagai wahana pendidikan, penelitian, pelestarian, informasi dan rekreasi untuk meningkatkan kecerdasan bangsa. Fungsi pendidikan diwujudkan dengan perpustakaan yang mampu meningkatkan kegemaran membaca penggunanya, fungsi penelitian diterapkan dengan menyediakan pelayanan untuk pemakai dalam memperoleh informasi sebagai bahan rujukan untuk kepentingan penelitian. Cara dalam meningkatkan kecerdasan kehidupan bangsa dengan meningkatkan kualitas pendidikan. Salah satu usaha dapat dilakukan melalui perpustakaan, karena perpustakaan merupakan institusi yang memiliki peran dalam menyediakan informasi bagi masyarakat. Pemberdayaan melalui perpustakaan ini berhubungan dengan bidang pendidikan. Perpustakaan adalah sebuah lembaga yang menjabarkan ilmu pengetahuan dan hasil-hasil pemikiran manusia dengan tidak henti-hentinya dan merupakan tempat belajar seumur hidup (Suharyanti, 2008).

Peran perpustakaan sebagai salah satu upaya mencerdaskan masyarakat Indonesia sudah jelas tercantum pada Undang-Undang Republik Indonesia Nomor 43 Tahun 2007 bab 1 pasal 1 tentang Perpustakan. Hal ini membuktikan bahwa penyelenggaraan perpustakaan merupakan salah satu upaya untuk turut membangun masyarakat yang intelektual di tengah-tengah perkembangan teknologi informasi yang sangat pesat. Adapun definisi perpustakaan sebagaimana tercantum dalam Undang-Undang Nomor 43 Tahun 2007 bab 1 pasal 1 tentang Perpustakaan pada bab I yang memuat tentang ketentuan umum perpustakaan, pada pasal 1 disebutkan bahwa Perpustakaan adalah institusi pengelola koleksi karya tulis, karya cetak, dan/ atau karya rekam secara professional dengan sistem yang baku guna memenuhi kebutuhan pendidikan, penelitian, pelestarian, informasi dan rekreasi bagi pemustaka.

Perpustakaan umum berperan dalam menyediakan kebutuhan informasi masyarakat, memperbaiki kesejahteraan masyarakat di sekitarnya, menyediakan buku-buku pengetahuan maupun keterampilan untuk mendukung keberhasilan kegiatan masyarakat, sehingga mereka mempunyai bekal dalam pengembangan diri. Perpustakaan sendiri memiliki fungsi yakni menjadi salah satu sumber informasi dan sarana pembelajaran bagi masyarakat, sedangkan masyarakat membutuhkan perpustakaan dalam rangka memenuhi kebutuhan informasi, dengan demikian perpustakaan dan masyarakat memiliki keterkaitan yang erat dan membutuhkan satu sama lain. Pada kenyataannya, keduanya masih berjalan sendiri-sendiri. Maka dari itu, agar keduanya bersinergi antara perpustakaan dan juga masyarakat, harus terdapat sebuah kegiatan yang dilakukan oleh perpustakaan untuk menarik masyarakat agar ikut serta dalam kegiatan.

Dari permasalahan terkait minat baca di Indonesia yang sangat rendah maka dari hasil analisis awal peneliti bahwasanya perpustakaan berperan dalam meningkatkan minat baca di Indonesia. Maka dari itu peneliti akan meneliti Perpustakaan Kota Banjar Patroman yang memiliki Program Wisata baca dan literasi yang merupakan salah satu upaya dalam meningkatkan minat baca pada anak usia dini. Terdapat keunikan dalam kegiatan ini, sesuai dengan nama Kegiatan yakni Wisata Baca dan Literasi, dalam kegiatannya program Wisata baca dan literasi ini dilakukan di luar perpustakaan agar anak-anak bisa berwisata di daerah Kota Banjar Patroman yang dibarengi dengan kegiatan membaca, agar anak-anak bisa senang serta gembira dalam mengikuti kegiatan.

Biasanya program pengembangan minat baca hanya merupakan kegiatan sosialisasi ataupun kegiatannya hanya di ruangan ketika melaksanakan kegiatan pengembangan minat baca, tetapi dalam program Wisata baca dan literasi yang di lakukan oleh Perpustakaan Kota Banjar dilaksanakan di tempat rekreasi yang terdapat di Kota Banjar Patroman, seperti Taman kota, Alunalun, atau Objek wisata Kota Banjar Patroman. 
Biasanya program kegiatan Wisata baca dan literasi ini dilaksanakan sambil berwisata, tetapi dengan keadaan pandemi Covid-19 seperti ini, membuat kegiatan tidak bisa dilaksanakan di luar dan harus di tempat yang lingkungannya terhindar Covid-19, maka perpustakaan pun melakukan perubahan jadwal serta tempat berlangsungnya kegiatan, sehingga kegiatan Wisata baca dan literasi dapat berlangsung meskipun keadaan pandemi Covid-19. Kegiatan Wisata baca dan literasi ini dilakukan di ruangan pelayanan Perpustakaan Kota Banjar, jadi perpustakaan juga disebut taman rekreasi untuk menambah ilmu pengetahuan.

Kegiatan Wisata baca dan literasi ini dilakukan setiap satu minggu satu kali, dengan menyesuaikan wilayah kecamatan. Peserta yang ikut dalam kegiatan ini dibatasi menjadi 20 orang dan beberapa guru yang mendampinginya. Program Wisata baca dan literasi ini bertujuan untuk pengembangan minat baca pada anak-anak sejak dini. Apalagi anak-anak pada masa pandemi Covid-19 seperti sekarang ini, anak-anak sering menggunakan Smartphone untuk bermain game ataupun melihat konten yang tidak semestinya dilihat dikarenakan masih dibawah umurDengan Program Wisata baca dan literasi ini bisa menjadikan anak-anak tidak kecanduan dalam menggunakan smartphone, tetapi yang dilihat berupa buku bacaan untuk meningkatkan pengetahuan dan meningkatkan minat baca pada anak. Selain itu mengubah stigma pada anak bahwasanya membaca buku itu merupakan hal yang seru dan tidak membosankan.

Diadakannya Program Wisata baca dan literasi untuk anak-anak PAUD, TK dan RA ini diharapkan anak-anak memiliki pengetahuan yang diperoleh dari keaktifan membaca bukan hanya teks saja, namun sudah mampu memahami konteks. Dengan pelaksanaan kegiatan di tengah pandemi Covid-19 seperti sekarang ini yang membuat anak-anak pun makin bersemangat dalam membaca buku dan tidak terhalang apapun, apalagi sampai anak menjadi kecanduan bermain Smartphone. Dengan begitu, Anak-anak PAUD, TK dan RA dapat meningkatkan minat baca, sehingga hasil guna dari membaca membuat potensi anak-anak dapat berkembang.

Dalam melaksanakan program Wisata baca dan literasi yang dilakukan oleh Perpustaakaan Kota Banjar, peneliti melihat bahwasanya perpustakaan menerapkan fungsi manajerial dalam pelaksanaan kegiatan sesuai dengan teori POAC (Planning, Organizing, Actuating, Controlling). Dengan penerapan fungsi manajemen kegiatan Wisata baca dan literasi pada pelaksanaan program Wisata baca Literasi yang dilaksanakan oleh Dinas Kearsipan dan Perpustakaan Kota Banjar Patroman akan berjalan sesuai dengan tujuan dengan efektif dan efisien, serta akan mencapai hasil yang maksimal di tengah berbagai keterbatasan dan kendala yang dihadapi.

Mengacu pada uraian diatas maka peneliti tertarik untuk meneliti bagaimana pengelolaan program wisata baca dan literasi oleh Perpustakaan Kota Banjar dilihat dari aspek POAC (Planning, Organizing, Actuating, Controlling) yang dilakukan oleh Perpustakaan Kota Banjar dalam kegiatan pengembangan minat baca anak. Hasil dari penelitian ini akan bermanfaat bagi perpustakaan umum di wilayah lain yang akan atau sedang mengembangkan program minat baca anak.

\section{TINJAUN PUSTAKA}

Perpustakaan Kota Banjar Patroman, Provinsi Jawa Barat merupakan salah satu perpustakaan kota yang mendukung dalam pengembangan minat baca untuk meningkatkan pendidikan dan pengetahuan masyarakat. Pada Perpustakaan Kota Banjar Patroman memiliki pelayanan berupa penyediaan pembelajaran dan sosialisasi tentang meningkatkan minat baca, untuk membantu masyarakat dalam meningkatkan ilmu pengetahuan. Kegiatan yang dilakukan dalam pengembangan minat baca oleh Perpustakaan Kota Banjar Patroman ini yaitu Wisata baca dan literasi yang kegiatannya untuk anak-anak Pendidikan Anak Usia Dini (PAUD), Taman Kanakkanak (TK) dan Raudhatul Athfal (RA) yang terdapat di Kota Banjar Patroman. Dengan Program 
tersebut yang bertujuan meningkatkan pengetahuan anak dengan cara membaca buku sejak dini. Selain itu, dengan program ini diharapkan peserta yang mengikuti kegiatan dapat meningkatkan minat baca, serta menanamkan dan mengembangkan kegiatan budaya literasi.

Perpustakaan Kota Banjar Patroman merupakan salah satu perpustakaan umum yang dikelola oleh pemerintah kota di dalam tanggung jawab Dinas Kearsipan dan Perpustakaan Kota Banjar Patroman. Perpustakaan umum merupakan lembaga layanan publik yang menyediakan pengetahuan dan informasi serta layanan, untuk semua lapisan masyarakat, tanpa memandang perbedaan umur, ras, gender, agama, kebangsaan, bahasa, status sosial, dan tingkat pendidikan (Sudarsono, 2006). Adanya Perpustakaan umum pada dasarnya dibangun untuk kepentingan masyarakat dalam mencari informasi ataupun referensi yang ditunjukan untuk melayani masyarakat sesuai kebutuhannya.

Peran Perpustakaan kota juga memiliki peran yang sangat strategis untuk pengembangan minat baca pada seluruh masyarakat terutama pada anak usia dini. Dalam menumbuhkan minat baca sejak dini tidaklah mudah. Perpustakaan sebagai lembaga yang bertugas untuk meningkatkan minat baca, khususnya perpustakaan umum, harus memiliki rencana atau strategi. Sebagai tahapan awal untuk menarik minat baca dapat dilakukan upaya menarik minat pemustaka untuk mengunjungi perpustakaan salah satunya dengan adanya program kegiatan pengembangan minat baca.

Pengembangan minat baca sangat penting untuk dilaksanakan dikarenakan menurut data UNESCO, minat baca masyarakat Indonesia hanya 0,001\%. Artinya, dari 1,000 orang Indonesia, Cuma 1 orang yang rajin membaca. Ini merupakan jumlah yang sangat sedikit, dengan keadaan seperti ini artinya masih kecil budaya membaca orang Indonesia. Riset yang bertajuk Worlds Most Literate Nations Ranked, dilakukan oleh Central Connecticut State University, menyatakan bahwa Indonesia menduduki peringkat ke-60 dari 61 negara dalam hal minat membaca. Selain itu pada data terbitan UNESCO pada tahun 2011 yang menyebutkan bahwa 497.497 jiwa penduduk Indonesia adalah buta huruf.

Dalam upaya untuk pengembangan minat baca, perpustakaan berperan penting dalam upaya meningkatkan kemampuan minat baca pada masyarakat. Dalam buku (Guidelines for Childrens Libraries Services, 2003) menyebutkan bahwa misi Layanan Perpustakaan untuk Anak adalah "By providing a wide range of materials and activities, public libraries provide an opportunity for children to experience the enjoyment of reading and the excitement of discovering knowledge and works of the imagination”, yang artinya "Dengan menyediakan berbagai macam materi dan aktivitas, perpustakaan umum memberikan kesempatan kepada anak- anak untuk merasakan kenikmatan membaca dan kegembiraan menemukan ilmu pengetahuan dan karya imajinasi”. Jadi bahwa misi layanan perpustakaan untuk anak adalah menyediakan berbagai bahan dan kegiatan yang dibutuhkan anak demi kepentingan menarik minat anak terhadap perpustakaan dan kegiatan membaca.

\section{METODE PENELITIAN}

Metode penelitian merupakan cara bagaimana penelitian dilaksanakan. Menurut William Chang dalam buku Metodologi Penulisan Ilmiah (Chang, 2002) dikatakan bahwasanya Metodologi adalah sebuah cara dalam mengerjakan karya ilmiah yang sesuai dengan prosedur. Metodologi juga merupakan salah satu cara jalan/jembatan untuk mengerjakan karya ilmiah agar sesuai dengan tujuan yang diteliti serta hasil yang telah direncanakan. Penelitian ini menggunakan metode kualitatif, dimana dalam metode kualitatif ini peneliti memperoleh gambaran dari fenomena atau permasalahan yang terdapat di lapangan atau memperoleh data dari objek yang diteliti berdasarkan proses wawancara serta observasi tanpa dilihat dari proses perhitungan. 
Menurut (Williams dkk., 2011) penelitian kualitatif adalah pengumpulan data pada suatu latar alamiah dengan menggunakan metode ilmiah dan dilakukan oleh orang atau peneliti yang tertarik secara alami. Menurut Maleong, metode kualitatif adalah sebuah penelitian ilmiah yang bertujuan untuk memahami suatu fenomena dalam kontak sosial sevara alami dengan mengedepankan proses interaksi komunikasi yang mendalam anatara peneliti dengan fenomena yang diteliti (Herdiansyah, 2010).

Metode penelitian deskriptif kualitatif menurut (Yani, t.t.) adalah metode penelitian yang berlandaskan filsafat post-positivisme yang biasa digunakan untuk meneliti kondisi objek yang alamiah, di mana peneliti berperan sebagai instrumen kunci dan melakukan melukiskan suatu keadaan secara objektif atau berdasarkan fakta-fakta yang tampak. Dapat ditarik kesimpulan bahwa metodologi kualitatif ialah suatu serangkaian kegiatan ilmiah yang dilakukan secara intensif, terinci dan mendalam tentang suatu program, peristiwa, dan aktivitas, baik pada tingkat perorangan, sekelompok orang, lembaga, atau organisasi untuk memperoleh pengetahuan mendalam tentang peristiwa tersebut.

Penelitian ini membahas tentang program kegiatan wisata baca dan literasi yang dilakukan oleh Perpustakaan Kota Banjar Patroman, secara umum bertujuan untuk memperoleh gambaran mengenai pengelolaan dalam program Wisata baca dan literasi sebagai bentuk dari pelayanan kepada masyarakat yang dilakukan oleh perpustakaan kota untuk pengembangan minat baca anak. Penelitian kualitatif adalah penelitian yang bermaksud untuk memahami fenomena tentang apa yang dialami oleh subjek penelitian, misalnya perilaku, persepsi, motivasi, tindakan, dan lain lain secara holistik, dan dengan cara deskripsi dalam bentuk kata kata dan bahasa, pada suatu konteks khusus yang alamiah dan dengan memanfaatkan berbagai metode alamiah (Meleong, 1989).

\section{HASIL DAN PEMBAHASAN}

Perpustakaan merupakan salah satu pusat informasi dan sumber ilmu pengetahuan. Selain melayani pemustaka dalam sirkulasi peminjaman atau pengembalian buku, Perpustakaan juga harus dapat melayani lebih aktif seperti berkomunikasi dengan anak, membacakan cerita untuk anak-anak, dan sebagainya. Tentu saja untuk melakukan layanan seperti ini dengan rutin, diperlukan kerjasama dengan Pendidikan Anak Usia Dini (PAUD), Taman Kanak-Kanak (TK) dan Raudhatul Athfal (RA) untuk dapat mengantarkan anak didiknya ke perpustakaan.

Perpustakaan Kota Banjar Patroman merupakan salah satu perpustakaan umum yang dikelola oleh pemerintah kota di dalam tanggung jawab Dinas Kearsipan dan Perpustakaan Kota Banjar Patroman sebagai bentuk pelayanan kepada masyarakat. Pelayanan yang dilakukan oleh Perpustakaan Kota Banjar ini untuk masyarakat yang salah satunya yaitu program pengembangan minat baca. Dalam melakasanakan program pengembangan minat baca yang dilakukan oleh Dinas Kearsipan dan Perpustakaan Kota Banjar menggunakan manajerial dalam pengelolaan program kegiatan yang diberi nama Wisata Baca dan Literasi. Kegiatannya dikhususkan untuk anak dari sekolah PAUD, TK dan RA yang terdapat di Kota Banjar Patroman.

Latar belakang dibuat nya kegiatan Wisata baca dan literasi ini untuk mengembangkan minat baca pada anak sejak dini, lalu diharapkan anak-anak memiliki pengetahuan yang diperoleh dari keaktifan membaca bukan hanya teks saja, namun sudah mampu memahami konteks. Selain itu, anak-anak sering menggunakan Smartphone untuk bermain game ataupun melihat konten yang tidak semestinya dilihat dikarenakan masih dibawah umur. Dengan Program Wisata baca dan literasi ini bisa menjadikan anak-anak tidak kecanduan dalam menggunakan smartphone, tetapi yang dilihat berupa buku bacaan untuk meningkatkan pengetahuan dan meningkatkan minat baca pada anak. 
Kegiatan Wisata Baca dan Literasi, dalam melaksanakan kegiatannya dilakukan di luar perpustakaan agar anak- anak bisa berwisata di daerah Kota Banjar Patroman yang dibarengi dengan kegiatan membaca, agar anak-anak bisa senang serta gembira dalam mengikuti kegiatan. Biasanya program pengembangan minat baca hanya merupakan kegiatan sosialisasi ataupun kegiatannya hanya di ruangan ketika melaksanakan kegiatan pengembangan minat baca, tetapi dalam program Wisata baca dan literasi yang di lakukan oleh Perpustakaan Kota Banjar dilaksanakan di tempat rekreasi yang terdapat di Kota Banjar Patroman, seperti Taman kota, Alunalun, atau Objek wisata Kota Banjar Patroman.

Tetapi dengan keadaan pandemi Covid-19 seperti ini kegiatan Wisata baca dan literasi ini dilakukan di dalam ruang layanan perpustakaan, dikarenakan untuk mengantisiapasi penyebaran Covid-19 di Kota Banjar. Meskipun dilaksanakan di dalam ruang layanan perpustakaan, pihak Perpustakaan Kota Banjar Patroman memberitahukan kepada para peserta bahwasanya perpustakaan juga dianggap sebagai tempat rekreasi bagi anak, karena didalam perpustakaan banyak koleksi buku untuk meningkatkan imajinasi dan pengetahuan anak serta membuat anak menjadi senang serta mengasikan.

Kegiatan Wisata baca dan literasi ini tidak dipungut biaya kepada para peserta semua di fasilitasi oleh pihak penyelanggara atau perpustakaan. Dengan hal ini para peserta bisa mengikuti kegiatan dengan tidak terbebani biaya. Hal ini didasari dengan bahwasanya perpustakaan melayani selruh masyarakat dengan tidak membebani, selain itu perpustakaan menjamin keberangkatan dan kepulangan para peserta, jadi semuanya ditanggung oleh pihak perpustakaan seperti makanan, hadiah, transportasi dan yang lainnya.

Waktu pelaksanaan program Wisata baca dan literasi ini dilakukan secara rutin sebanyak 2 kali dalam 1 bulan atau 24 kali dalam setahun dengan peserta dibatasi untuk mengikuti kegiatan Wisata baca dan literasi dengan kuota 20 orang dan beberapa guru yang mendampinginya. Dengan peserta yang berbeda-beda setiap pelaksanaannya, para peserta ini terdiri dari anak PAUD, TK dan RA. Dalam mengundang peserta Perpustakaan bekerjasama dengan Ikatan Guru dari lemabaga sekolah seperti Ikatan Guru Pendidikan Anak Usia Dini (IGPAUD), Ikatan Guru Taman Kanakkanak (IGTK) dan Ikatan Guru Raudhatul Athfal (IGRA).

Dengan melampirkan surat kegiatan kepada ikatan guru tersebut, maka Perpustakaan Kota Banjar Patroman yang menyelenggarakan kegiatan tidak perlu untuk keliling sosialisasi kepada setiap sekolah PAUD, TK dan RA, tetapi sudah dibantu oleh Ikatan Guru dari sekolah untuk menyebarkan informasi kegiatan kepada sekolah PAUD, TK dan RA yang terdapat di Kota Banjar. Kegiatan dalam program wisata baca dan literasi ini seperti membaca buku, story telling yang dibacakan oleh pustakawan, menggambar dan menulis, kuis berhadiah, memperkenalkan perpustakaan sebagai tempat yang asyik.

\section{A. PENGELOLAAN PROGRAM WISATA BACA DAN LITERASI MENGGUNAKAN ANALISIS POAC}

Dalam pengelolaan kegiatan Wisata baca dan literasi ini menggunakan aspek Planning, Organizing, Actuating, dan Controlling POAC) untuk mengatur pelaksanaan kegiatan ini, dengan penerapan fungsi manajemen tersebut, diharapkan pelaksanaan program Wisata baca dan literasi oleh para pustakawan akan mencapai hasil yang maksimal di tengah berbagai keterbatasan dan kendala yang dihadapi. Menurut Terry (Deddy Supriady \& Riyadi, 2005) perencanaan adalah upaya untuk memilih dan menghubungkan fakta-fakta dan membuat serta menggunakan asumsiasumsi mengenal masa yang akan datang dengan jalan dan merumuskan kegiatan- kegiatan yang di perhatikan untuk mencapai hasil yang di inginkan. Untuk membentuk kegiatan yang kuat dan kerjasama yang baik diperlukan suatuplanning yang matang. 
Perencanaan merupakan suatu proses untuk menentukan tujuan serta sasaran yang ingin dicapai dengan mengambil metode yang strategis guna mencapai tujuan tersebut. Planning adalah suatu fungsi yang mencakup proses menentukan sasaran, kebijakan, produk, jasa, alat-alat, pengeluaran, jadwal, lokasi, personalia, hubungan organisasi (Supriyatna, 2009).

Perencanaan yang dilakukan pada Dinas Kearsipan dan Perpustakaan Kota Banjar Patroman dalam kegiatan Wisata Baca dan Litersi ini dimulai dari penentuan rencana yang prima dalam segala hal, tahapan proses yang baik, peningkatan keterampilan dan kreatifitas dalam bekerja, lalu peningkatan kepekaan dan inovatif dalam melaksanakan kegiatan. Perencanaan-perencanaan tersebut dilaksanakan oleh seluruh panitia pelaksana yang ada pada kegiatan Wisata Baca dan Literasi. Aspek yang diperhatikan dalam perencenaan ini, diantaranya adalah tujuan diadakanya kegiatan, kebijakan dalam kegiatan, sumber daya yang mengikuti kegiatan, jangka waktu dalam kegiatan.

Latar belakang dibuatnya kegiatan ini untuk mengembangkan minat baca pada anak sejak dini, selain itu untuk memperkenalkan perpustakaan kepada anak, serta diharapkan anak-anak memiliki pengetahuan yang diperoleh dari keaktifan membaca bukan hanya teks saja, namun sudah mampu memahami konteks. Alasan memberikan nama kegiatan ini Wisata baca dan literasi ini adalah untuk memberikan inovasi baru cara mengembangkan minat baca pada anak, dengan berwisata di luar ruangan dibarengi membaca buku. Hal itu membuat anak-anak antusias mengikuti kegiatan Wisata Baca dan Literasi, dikarenakan kegiatan membaca yang dilakukan dikemas dengan berbentuk rekreasi pada anak, agar anak bisa mengembangkan imajinasi dan pengetahuan.

Pihak yang terlibat dalam kegiatan ini yaitu Dinas Kearsipan dan Perpustakaan Kota Banjar Patroman, IGPAUD, IGTK, IGRA dan Pemerintahan pusat Kota Banjar Patroman. Dari pihak tersebut membuat kegiatan ini berjalan dengan lancar sesuai dengan tujuan dibuatnya kegiatan ini. Dalam menetapkan target atau tujuan yang sudah dikonsep dalam kegiatan Wisata Baca dan Literasi, panitia penyelenggara menggunakan keputusan- keputusan dari Kerangka Acuan Kerja (KAK) yang sudah dibuat oleh Dinas Kearsipan dan Perpustakaan Kota Banjar Patroman, didalamnya terdapat kebutuhan kegiatan, Tujuan Kegiata, anggaran kegiatan, sistem pelaksanaan kegiatan dan latar belakang kegiatan.

Dengan menggunakan KAK, memudahkan panitia penyelenggara dalam melaksanakan kegiatan. Ketika dalam pelaksanaan kegiatan tidak sesuai dengan KAK , maka panitia menggunakan perencanaan cadangan yang sudah ditetapkan, agar kegiatan masih berlangsung sesuai dengan tujuan diadakannya kegiatan Wisata Baca dan Literasi. Untuk mencapai perencanaan yang sesuai dengan Kerangka Acuan Kerja (KAK) Perpustakaan Kota Banjar membentuk struktur kepanitiaan dengan cara menyimpan panitianya sesuai dengan keahlian atau dari setiap panitia pelaksananya harus bisa saling backup satu sama lain.

Panitia penyelenggaranya merupakan pegawai atau pustakawan di Dinas Kearsipan dan Perpustakaan Kota Banjar, jadi kerjasama tim nya sudah terbentuk. Anggaran dana kegiatan Wisata baca dan literasi ini dilihat dari Kerangka Acuan Kerja (KAK) jumlah keseluruhannya bersumber dari dana Anggaran Pendapatan dan Belanja Daerah (APBD) Kota Banjar Tahun 2021, yaitu sebesar Rp. 9.656.800,-. Dari dana tersebut sudah meliputi konsumsi, transportasi, logistik dan acara. Kendala yang dihadapi dalam proses perencanaan adalah ketika perumusan konsep kegiatan dan topik kegiatan, dikarenakan setiap pertemuan diharuskan berbeda konsep serta topik, agar kegiatan tidak terlalu monoton serta membuat para panitia dan peserta tidak merasakan bosan dalam pelaksanaan kegiatan. 
Dari proses perencanaan diatas bisa disimpulkan bahwasanya perencanaan yang dilakukan oleh Dinas Kearsipan dan Perpustakaan Kota Banjar Patroman dalam kegiatan Wisata Baca dan Literasi, menyesuaikan dengan Kerangka Acuan Kerja (KAK) yang didalamnya terdapat anggaran, kebutuhan kegiatan, konsep kegiatan, tujuan kegiatan danoutput yang didapat oleh peserta yang mengikuti kegiatan.

\section{B. PENGORGANISASIAN}

Menurut (Schermerhon, 1996) pengorganisasian adalah proses mengatur orang-orang dan sumber daya lainnya untuk bekerja ke arah tujuan bersama. Pengorganisasian merupakan suatu proses penentuan, pengelompokan, pengaturan dan pembentukan pola hubungan kerja dari orang untuk mencapai sesuai dengan tugasnya. Fungsi, tujuan pengorganisasian dilakukan perencanaan, jadi pengorganisasian dilakukan setelah adanya fase perencanaan. Pengorganisasian yang dilakukan Oleh Dinas Kearsipan dan Perpustakaan Kota Banjar Patroman pada kegiatan Wisata baca dan literasi dilaksanakan dengan melakukan pembagian tugas pada masing-masing sesuai dengan keahlian yang terdapat pada pustakawan sebagai panitia penyelenggara yang meliputi penugasan setiap aktifitas, membagi pekerjaan ke dalam setiap tugas yang spesifik, dan menentukan siapa yang memiliki hak untuk mengerjakan beberapa tugas.

Untuk menunjang kegiatan maka dibentuklah beberapa divisi yang sesuai dengan tugasnya terdapat 15 orang panitia yang terlibat dalam kegiatan ini, semuanya termasuk pegawai pada bidang perpustakaan, lalu pada pembagian tugas dan fungsinya yaitu Ketua Pelaksana, Sekretaris dan Bendahara, serta beberapa divisi yang diantaranya Divisi Acara, Divisi Humas, Divisi Logistik/Peralatan, Divisi Konsumsi, Divisi Publikasi Dokumentasi dan Dekorasi, dan Divisi Transportasi. Dalam menetapkan tugas, pokok dan fungsi para panitia penyelenggara, semua anggota panitia diharuskan bisa saling backup dan bekerjasama dalam melaksanakan kegiatan serta tidak terlalu mengedepankan egois dalam melakukan tugasnya. Dengan pembagian tugas sesuai dengan kehaliannya, maka para panitia bekerja sesuai dengan tugas masing- masing dan tidak terlalu ikut campur dengan tugas orang lain.

Maka dari itu, pentingnya pengorganisasian, menyebabkan timbulnya sebuah struktur organisasi, yang dianggap sebagai sebuah kerangka sebuah kerangka yang masih dapat menggabungkan usaha-usaha mereka dengan baik. Dengan kata lain, salah satu bagian penting tugas pengorganisasian adalah mengharrmonisasikan anggota kelompok yang terdapat didalamnya dengan perbedaan, mempertemukan macam-macam kepentingan dan memanfaatkan kemampuankemampuan kesemuanya kesuatu arah tertentu (Terry \& Rue, 2005). Maksud dari hal tersebut adalah dapat dihasilkannya sinergisme, yang berarti perlu adanya tindakan-tindakan untuk mengelompokkan semua kemampuan yang sesuai menjadi satu tempat dan memanfaaatkan kemampuan tersebut agar dapat berguna bagi kegiatan Wisata baca dan literasi yang diselenggarakan oleh Dinas Kearsipan dan Perpustakaan Kota Banjar.

Kendala yang biasa dihadapi pada pengorganisasian yaitu ketika terdapat panitia yang tidak hadir dikarenakan terdapat tugas atau tidak masuk bekerja, maka kekosongan tugas tersebut lambat dalam melakukanbackup terhadap tugas yang kosong tersebut. Biasanya yang langsung melakukan backup tersebut yaitu ketua pelaksana, ketika sudah adanya panitia yang mampu untuk backup maka ketua pelaksana langsung memberikan tugas nya kepada panitia yang backup tersebut. Dari pengorganisasian dalam melaksanakan kegiatan Wisata baca dan literasi yang dilakukan oleh Dinas Kearsipan dan Perpustakaan Kota Banjar menggunakan cara membagi tugas, pokok dan fungsi kepada para pustakawan sebagai panitia penyelenggara yang tersebar dalam 6 divisi, dengan cara itu ketika pelaksanaan para panitia melakukan dengan tugas masing-masing dan saling membantu satu sama lain sesuai dengan komitmen yang sudah disepakati ketika terdapat adanya anggota panitia yang tidak mengikuti kegiatan, maka panitia yang lain saling 
membantu terhadap kekosongan panitia yang tidak mengikuti kegiatan.

\section{PELAKSANAAN}

Menurut (Terry \& Rue, 2005) pelaksanaan adalah usaha yang dilakukan untuk menggerakan anggota-anggota kelompok sedemikian rupa hingga mereka akan berkeinginan dan akan berusaha untuk mencapai sasaran yang telah di tentukan dalam perencanaan. Pelaksanaan merupakan aktualisasi dari perencanaan dan pengorganisasian secara kongkrit. Perencanaan dan pengorganisasian tidak akan mencapai tujuan yang ditetapkan tanpa adanya aktualisasi dalam bentuk kegiatan. Singkatnya perencanaan mencakup kegiatan yang dilakukan seorang yang ditetapkan manager untuk mengawali dan melanjutkan kegiatan yang telah di tetapkan oleh unsur perencanaan dan pengorganisasian agar tujuan-tujuan dapat tercapai (Terry \& Rue, 2005).

Dalam pelaksanaan kegiatan Wisata baca dan literasi yang dilakukan oleh Dinas Kearsipan dan Perpustakaan Kota Banjar Patroman kegiatan sudah berjalan dengan lancar, meskipun keadaan pandemi Covid-19 seperti sekarang ini, kegiatan ini masih terus berlangsung dengan dibatasi jumlah peserta nya menjadi 20 orang yang terdiri dari guru pendamping dan juga para siswa nya. Dengan dibatasi nya jumlah peserta, tidak menghambat jalannya kegiatan ini, tetapi dengan terbatasnya jumlah peserta, beberapa sekolah berebut untuk mendaftar dan list yang daftar dari sekolah lumayan banyak.

Proses kegiatan Wisata baca dan literasi ini mempunyai susunan acara yang sesuai dengan konsep perencanaan, hampir semua tugas dalam proses pelaksanaan dilakukan oleh divisi acara, berikut acara dalam kegiatan wisata baca dan literasi yaitu membaca buku, story telling yang dibacakan oleh pustakawan, menggambar dan menulis, kuis berhadiah, memperkenalkan perpustakaan.

\section{WAKTU PELAKSANAAN PROGRAM}

Wisata baca dan literasi ini dilakukan secara rutin sebanyak 2 kali dalam 1 bulan atau 24 kali dalam setahun. Dengan peserta yang berbeda-beda setiap pelaksanaannya dan juga tema setipa pertemuan berbeda- beda. Maka dari itu kendala yang dihadapi ketika proses pelaksanaan yaitu penentuan tema yang harus berbeda dari setiap sekolah yang mengikuti kegiatan Wisata Baca dan Literasi. Dengan berbeda tema kegiatan dalam setiap pelaksanaannya membuat kegiatan Wisata baca dan literasi ini tidak terlalu monoton dengan hanya menggunakan satu tema dalam kegiatannya, meskipun kegiatan ini merupakan program pengembangan minat baca anak, tetapi dalam proses pelaksanaannya harus terdapat hal yang menarik dari setiap pertemuannya.

Maka dari itu para panitia penyelenggara dan juga konseptor kegiatan Wisata baca dan literasi harus bisa berpikir kreatif dalam menentukan tema dan juga menyesuaikan dengan kebutuhan untuk menunjang pengembangan minat baca untuk anak sejak dini. Seperti contoh tema yang sesuai dengan pengembangan minat baca dan peserta yang menerima tema tersebut yaitu Tema "Menumbuhkan minat Baca anak sejak dini” kepada peserta RA Miftahul Amanah (Kec. Purwaharja) dengan tema tersebut para peserta diberikan penjelasan bahwasanya membaca itu membuat kreativitas dan imajinasi semakin meningkat, serta memberikan pengetahuan baru dari hasil membaca. Lalu untuk kegiatan selanjutnya dengan peserta yang berbeda maka temanya pun berbeda, mesikpun berbeda tema tetapi tujuannya yaitu untuk meningkatkan minat baca anak sejak dini.

Kendala yang dihadapi ketika pelaksanaannya pernah terjadi suatu permasalahan yaitu miskomunikasi atau salah menyampaikan informasi antara panitia dan juga para pendamping peserta, seperti pergantian jadwal yang sudah di tetapkan tetapi dikarenakan adanya vaksinasi untuk pegawai kedinasan, maka harus berubah jadwalnya, lalu terdapat juga miskomunikasi dalam antar-jemput para peserta dan miskomunikasi antar panitia penyelenggara. Dari beberapa kendala 
miskomunikasi pihak panitia bisa mengatasi masalah dengan cara mengklarifikasi dan mengevaluasi agar tidak terjadi miskomunikasi. Dalam pelaksanaannya pernah terjadi miskomunikasi atau salah menyampaikan informasi antara panitia dan juga para pendamping peserta, seperti pergantian jadwal yang sudah di tetapkan tetapi dikarenakan adanya vaksinasi untuk pegawai kedinasan, maka harus berubah jadwalnya, lalu terdapat juga miskomunikasi dalam antar-jemput para peserta dan miskomunikasi antar panitia penyelenggara. Dari beberapa kendala miskomunikasi pihak panitia bisa mengatasi masalah dengan cara mengklarifikasi dan mengevaluasi agar tidak terjadi miskomunikasi.

\section{E. PENGAWASAN}

Menurut (Effendi, 2014) mengemukakan bahwa pengawasan merupakan fungsi manajemen yang paling esensial, sebaik apa pun kegiatan pekerjaan tanpa adanya dilaksanakan pengawasan pekerjaan itu tidak dapat dikatakan berhasil. Sedangkan menurut (Fahmi \& Ramdani, 2014) mengatakan bahwa pengawasan secara umum dapat di definisikan sebagai cara suatu organisasi mewujudkan kinerja yang efekif dan efisien, serta lebih jauh mendukung terwujudnya visi dan misi suatu orgainisasi. Pengawasan bisa dikatakan sebagai tahap akhir dalam sebuah kegiatan ataupun pekerjaan yang telah dilakukan oleh organisasi agar mengetahui kekurangan serta kelebihan ketika dalam pelaksanaan. Fungsi dari pengawasan adalah menentukan apakah rencana awal perlu direvisi, melihat hasil dari kinerja selama ini. Jika dirasa butuh ada perubahan, maka seorang ketua pelaksana akan kembali pada proses perencanaan. Di mana akan merencanakan sesuatu yang baru, berdasarkan hasil dari pengawasan.

Pada proses pengawasan dalam Kegiatan Wisata baca dan literasi ini yang bertugas sebagai evaluator dilakukan oleh Ibu Nia Kania sebagai Kepala Dinas Kearsipan dan Perpustakaan Kota Banjar dan Ibu Sri sebagai Kepala Bidang Perpustakaan. Bentuk pengawasan yang dilakukan pada kegiatan Wisata baca dan literasi ini yaitu pengawasan langsung dan tidak langsung oleh kepala Dinas Kearsipan dan Perpustakaan Kota Banjar serta kepala Bidang Perpustakaan, pengawasan internal yang dilakukan oleh panitia penyelenggara dan eksteral oleh pihak Pemerintahan Kota.

Berikut penjelasan dari bentuk pengawasan dalam kegiatan wisata baca dan literasi, pertama yakni pengawasan langsung. Menurut (Marigan, 2004) Pengawasan langsung merupakan pengawasan yang dilakukan seorang pimpinan terhadap kegiatan-kegiatan yang sedang berlangsung, pengawasan ini dapat berbentuk inspeksi langsung dan laporan dari tempat. Pada pengawasan langsung ini dilakukan oleh Kepala Bidang Perpustakaan yakni Ibu Sridengan cara memonitor secara langsung proses berjalannya kegiatan yang dilakukan oleh panitia. Proses pemantauan kinerja yang dilakukan oleh kepala bidang perpustakaan dengan pemantauan kesiapan para panitia dalam melaksanakan kegiatan, mempersiapkan segala bentuk kebutuhan kegiatan dengan melakukan koordinasi dengan ketua pelaksana. Terkadang ketika kepala Dinas Kearsipan dan Perpustakaan Kota Banjar Patroman sedang berada di kantor serta tidak terdapat kesibukan tugas kedinasan, beliau ikut serta dalam proses pengawasan langsung.

Kedua pengawasan tidak langsung. menurut (Marigan, 2004) pengawasan tidak langsung Merupakan pelaksanaan pengawasan yang dilakukan dari jarak jauh dengan melalui laporan yang dapat dilihat dari 1) laporan tertulis seperti Lembar penanggungjawaban dan laporan hasil kerja kegiatan yang diberikan oleh ketua pelaksana kepada evaluator kegiatan, 2) laporan lisan seperti melaporkan secara lisan dengan berbicara langsung hasil kegiatan oleh ketua pelaksana kepada evaluator kegiatan. Dalam memberikan laporan yang dilakukan oleh ketua pelaksana ini dilakukan secara birokrasi di Dinas Kearsipan dan Perpustakaan Kota Banjar Patroman, seperti ketua pelaksana melaporkan kepada Kepala Bidang Perpustakaan sebagai evaluator kegiatan terlebih dahulu sebelum kepada Kepala Dinas Kearsipan dan Perpustakaan Kota Banjar Patroman yang juga sebagai evaluator kegiatan. Jadi birokrasi tertinggi dalam kegiatan ini yaitu Kepala Dinas 
Kearsipan dan Perpustakaan Kota Banjar.

Ketiga pengawasan internal. Pengawasan internal merupakan pengawasan dengan kebijakan dan prosedur yang sesuai dengan terjadi sebenarnya di lapangan untuk melindungi dari penyalahgunaan untuk memastikan secara langsung untuk mendapatkan informasi yang akurat dan memastikan para anggota melakukan tugas nya sesuai dengan peraturan dan dipatuhi sebagaimana semestinya. Pengawasannya dilakukan secara langsung oleh pemimpin kebijakan (Niswonger, 1999). Dalam pengawasan internal ini dilakukan oleh ketua pelaksana kegiatan Wisata baca dan literasi untuk memantau langsung para anggota panitia dalam melaksanakan tugas, pokok dan fungsi yang sesuai dengan divisi/seksi. Dengan begitu ketua pelaksana dapat melihat kinerja anggota dalam melaksanakan kegiatan Wisata Baca dan Literasi.

Keempat pengawasan external. Menurut (Baswir, 1998) Pengawasan external adalah bentuk pengawasan yang dilakukan oleh suatu unit pengawasan yang sama sekali berasal dari luar lingkungan penyelenggara. Selain itu menurut (Susanto, 2016) pengawasan external adalah pengawasan yang dilakukan dengan melihat kegiatan untuk mengetahui dan menilai kenyataan yang sebenarnya tentang pelaksanaan kegiatannya, apakah sesuai dengan yang semestinya atau tidak.

Pihak pengawasan external dilakukan oleh pihak pemerintahan kota seperti Walikota Banjar ataupun Bunda Literasi, pengawasan nya berbentuk langsung dengan survey ke lapangan atau kegiatan berlangsung dan melihat kegiatannya apa sesuai dengan pengajuan kegiatan atau tidak, selain itu pengawasannya bisa berbentuk tidak langsung, jadi dari pihak Dinas memberikan laporan kepada pemerintahan yang berbentuk Laporan Penanggungjawaban dan hasil kegiatan. Karena pihak penyelenggaranya dari Lembaga pemerintahan maka terdapat pengawasan dari pihak pusat pemerintahan kota. Misalnya pihak pemkot kota Banjar yaitu Walikota Banjar memantau langsung proses berjalannya kegiatan,ketika terdapat kekurangan dalam pelaksanaan, maka Walikota Banjar memberikan masukan saran atau kritik untuk kegiatan WBL ini.

Maka dari itu, dalam menggunakan bentuk pengawasan itu tergantung dari kebijakannya dalam menggerakan kegiatan , untuk itu keberhasilan suatu organisasi ataupun instansi dapat diukur dari proses kegiatan pengawasan yang dilakukan oleh seorang pimpinan. Aspek yang dievaluasi dalam kegiatan Wisata baca dan literasi yaitu keseuaian antara konsep perencanaan dan pelaksanaan, keterlaksanaan program, kendala-kendala ketika pelaksanaan, dampak dan pengaruh terhadap peserta setelah mengikuti kegiatan dan kesesuaian tugas anggota dalam melaksanakan kegiatan.

Dalam beberapa aspek tersebut evaluator dapat mengetahui hal apa saja yang perlu dievaluasi dalam proses pelaksanaan kegiatan. Indikator keberhasilan dalam melaksanakan Program kegiatan Wisata baca dan literasi yang dilakukan oleh Dinas Kearsipan dan Perpustakaan Kota Banjar Patroman yaitu dengan adanya program ini para peserta atau anak-anak usia dini dari beberapa sekolah PAUD, TK dan RA dapat mengembangkan minat baca untuk meningkatkan kreativitas, imajinasi, dan pengetahuan anak setelah mengikuti kegiatan Wisata baca dan literasi ini.

Hal ini terus dipantau perkembangan para peserta melalui guru pendamping dan terus menerus dievaluasi dari hasil laporan dari guru pendamping, selain itu agar setelah mengikuti pelaksanaannya para peserta meningkat, lalu para guru pendamping berperan dalam mengawasi pengembangan minat baca pada anak didiknya. Maka peran Perpustakaan dalam mencerdaskan kehidupan bangsa terwujud dengan salah satu kegiatan yang dilakukan oleh Dinas Kearsipan dan Peprustakaan Kota Banjar Patroman yaitu kegiatan Wisata Baca dan Literasi. 
Kendala yang dihadapi ketika proses pengawasan yaitu selalu terjadi perubahan dalam koordinasi pada evaluator, dikarenakan evaluator yang tidak mudah untuk ditemui dan selalu berbeda dalam menyampaikan informasi kepada para evaluator. Selain itu terdapat kurangnya tranparansi informasi ketika melakukan penyampaian hasil kegiatan kepada evaluator, dikarenakan para panitia harus menyampaikan hal yang baik kepada para evaluator.

Pada pengawasan kegiatan Wisata baca dan literasi ini, menggunakan bentuk pengawasan langsung yang dilakukan oleh evaluator (Kepala Dinas dan Kepala bidang perpustakaan) dengan cara mengawasi langsung berjalannya kegiatan Wisata Baca dan Literasi, lalu pengawasan tidak langsung yang dilakukan hanya berbentuk hasil laporan penanggung jawaban (LPJ) yang dibuat oleh panitia dan diserahkan kepada evaluator, kemudian pengawasan internal dilakukan oleh ketua pelaksana yang mengawasi langsung dan melihat kinerja para panitia ketika proses kegiatan. Dan terakhir menggunakan pengawasan external yang dilakukan oleh pihak Pemerintahan Kota (Walikota atau perangkat Pemkot lainnya) dengan melakukan sidak langsung melihat proses kegiatan Wisata Baca dan Literasi.

\section{KESIMPULAN}

Kegiatan Wisata baca dan literasi menggunakan aspek Planning, Organizing, Actuating, Controlling (POAC) untuk memudahkan dalam pelaksanaannya. Perencanaan yang dilakukan oleh Dinas Kearsipan dan Perpustakaan Kota Banjar Patroman dalam kegiatan Wisata baca dan literasi menggunakan konsep yang telah ditentukan dan tercantum dalam Kerangka Acuan Kerja (KAK). Pengorganisasian dalam kegiatan Wisata baca dan literasi dilakukan dengan pembagian tugas sesuai dengan keahliannya dengan SDM sebanyak 15 orang Pustakawan, pembagian tugas tersebut dibagi menjadi 6 Divisi diantaranya Divisi Acara, Divisi Humas, Divisi Logistik, Divisi Konsumsi, Divisi PDD dan Divisi Transportasi. Pelaksanaan kegiatan Wisata baca dan literasi dilakukan sebanyak 2 kali dalam satu bulan atau 24 kali dalam satu tahun. Dengan beberapa susunan acara seperti membaca buku, story telling yang dibacakan oleh Pustakawan, menggambar dan menulis, kuis berhadiah dan mengenalkan perpustakaan sejak dini. Pengawasan yang dilakukan dalam kegiatan Wisata baca dan literasi ini menggunakan pengawasan langsung, Pengawasan tidak langsung, pengawasan internal dan pengawasan external hal ini dapat mengetahui pelaksanaan kegiatan Wisata baca dan literasi oleh para evaluator yaitu Kepala Dinas Kearsipan dan Perpustakaan Kota Banjar Patroman, Kepala Bidang Perpustakaan dan Pemkot Banjar.

\section{DAFTAR PUSTAKA}

Aditama, Roni Angger. (2020). Pengantar Manajemen : Teori dan Aplikasi. Kepanjen: AE Publishing.

Ainia, Khurotin. (2019). "Pengembangan Media Pizza Cerbung (Cerita Bersambung) untuk Meningkatkan Minat Baca Siswa Kelas Idi SDN Gelam II Candi Sidoarjo.” Prosiding Seminar Nasional PGSD Unikama 25- 39.

Artana, I Ketut. (2017). “ANAK, MINAT BACA, DAN MENDONGENG.” Acarya Pustaka Vol 3, No 1 26-36.
Arumsari, Nurul Rizka.
( 2017). “PENERAPAN
PLANNING, ORGANIZING, ACTUATING, DAN CONTROLLING DI UPTD DIKPORA KECAMATAN JEPARA.” Jurnal Unpand 841-848.

Basuki, S. (2006). Metode Penelitian. Jakarta: Wedatama Widya Bekerjasama dengan FIB UI.

Baswir, R. (1998). Akuntansi Pemerintahan Indonesia. 
Chang, W. (2002). Metodologi Penulisan Ilmiah Teknik Penulisan Esai, Skripsi.

Dakhi, Yohannes. 2016. "IMPLEMENTASI POAC TERHADAP KEGIATAN ORGANISASI DALAM MENCAPAI TUJUAN TERTENTU.” Jurnal Warta Edisi : 50 1-7.

Dwiyantoro. (2019). "Peran Taman Bacaan Masyarakat Mata Aksara dalam menumbuhkan minat baca pada masyarakat.” Jurnal Kajian Informasi \& Perpustakaan Vol. 7, No. 1 19-32.

Deddy Supriady, B., \& Riyadi. (2005). Perencanaan pembangunan daerah: Strategi menggali potensi dalam mewujudkan otonomi daerah. Gramedia Pustaka Utama.

Effendi, U. (2014). Asas manajemen. Jakarta: Rajawali Pers.

Fahmi, I., \& Ramdani, Z. (2014). Profil kekuatan karakter dan kebajikan pada mahasiswa berprestasi. Psympathic: Jurnal Ilmiah Psikologi, 1(1).

Herdiansyah, H. (2010). Metodologi penelitian kualitatif untuk ilmu-ilmu sosial.

Handoko, T Hani. (2003). Manajemen. Yogyakarta: BBFE.

HS, Lasa. (2009). “Peran Perpustakaan dan Penulis Dalam Peningkatan Minat Baca Masyarakat.” Visi Pustaka Edisi: Vol. 11 No. 2 109-127.

Indonesia. (2007). Undang-Undang Republik Indonesia Nomor 43 Tahun 2007 Tentang Perpustakaan. Jakarta: Perpusnas.

-. (2007). Undang-Undang RI Nomor 43 Tahun 2007 tentang Perpustakaan. Jakarta: Perpustakaan Nasional RI.

Bidang Informatika Diskominfo Kota Banjar, (2017), penyunt. 2017. Informasi Kegiatan Dinas Kearsipan dan Perpustakaan Kota Banjar. 20 September. https://banjarkota.go.id/.

Irhandayaningsih, Ana. (2019). "Menanamkan Budaya Membaca pada Anak Usia Dini.” ANUVA Volume 3 (2) 109-118.

Kristyarini, Eny Dwi. (2007). "PERAN PERPUSTAKAANDALAM MENANAMKAN MINAT BACA SEJAK USIA DINI.” Media Pustakawan (e-Journal Perpusnas) vol 14, No 3\&4 146151.

Mahbudin. (2020). Peran Pemerintah Dalam Membangun Budaya L Literasi Indonesia, 13 Juli. https://bdkjakarta.kemenag.go.id/ berita/peran-pemerintah-dalam- membangunbudaya-literasi- indonesia.

Marigan, M. S. (2004). Dasar-Dasar Administrasi.

Meleong, L. J. (1989). Metologi penelitian kualitatif. PT Remaja Rosdakarya.

Niswonger. (1999). Prinsip-Prinsip Akuntansi (A. Sirait \& H. Gunawan, Penerj.; 19 ed.). Erlangga. 
Rosalia, Sholehah, dan Ludviana Eka Purnami. (2019). "PENDIDIKAN KARAKTER MENGAJAK ANAK USIA DINI UNTUK MENUMBUHKAN MINAT BACA.” Jurnal PBSI FKIP UAD 259- 261.

Santoso, Hari. (2011). "MEMBANGUN MINAT BACA ANAK USIA DINI MELALUI PENYEDIAAN BUKU BERGAMBAR.” Artikel Pustakawan Perpustakaan UM 1-16.

Siregar, A. R. (2012). Pembinaan Minat Baca Anak

Sugiono. (2013). Metode Penelitian: Pendekatan Kuantitatif, Kualitatif dan R\&D. Bandung: Alfabeta.

Sulistia, M, L. (1995). Manajemen Perpustakaan Sekolah. Jakarta: Depdikbud.

Syadad. (2008). “POAC (Planning, Organization, Actuating, Controlling) .” Jurnal MKMI Vol. 2 No 1 1-15.

Schermerhon. (1996). Management. John Wiley \& Sons, Inc.

Suharyanti. (2008). Pengantar dasar ilmu perpustakaan. LPP UNS.

Supriyatna, D. (2009). Manajemen. Universitas Terbuka.

Susanto, A. (2016). Manajemen peningkatan kinerja guru: Konsep, strategi dan implementasinya. Kencana.

Terry, G. R., \& Rue, L. W. (2005). Dasar-dasar manajemen (G. A. Ticoalu, Penerj.; 9 ed.). Bumi Aksara.

Terry, George R, dan Leslie W Rue. (2019). Dasar-Dasar Manajemen : Edisi Revisi. Jakarta Timur: Bumi Aksara.

Tim Pustaka Setia. (2001). UUD"45 : Undang-Undang Dasar Republik Indonesia Tahun 1945 Amandemen Kedua. Bandung: Pustaka Setia.

Williams, D. D., South, J. B., Yanchar, S. C., Wilson, B. G., \& Allen, S. (2011). How do instructional designers evaluate? A qualitative study of evaluation in practice.

Wahyuni, Sri. (2009). “MENUMBUHKAN PENGEMBANGAN MINAT BACA MENUJU MASYARAKAT LITERAT.” Jurnal Diksi Vol 16 No 2 179-189.

Educational Technology Research and Development, 59(6), 885-907. https://doi.org/10.1007/s11423-011-9211-8

Yani, J. A. (t.t.). Sugiyono. 2017. Metode Penelitian Kuantitatif, Kualitatif, Dan R\&D. Bandung: Alfabeta. Ferrari, JR, Jhonson, JL, \& McCown, WG (1995). Procrastination And Task Avoidance: Theory, Research \& Treatment. New York: Plenum Press. Yudistira P, Chandra. Diktat Kuliah Psikometri. Fakultas Psikologi Universitas. 